\title{
Associated faunas of seaweeds and seagrasses in the Southern Rakhine coastal zone
}

\begin{abstract}
A total of 62 taxa of associated faunas were recorded from seaweeds and seagrasses of Southern Rakhine coastal zone. The percentage of associated faunal composition was represented by $55 \%$ of Annelida, $27 \%$ of Arthropoda, $11 \%$ of Mollusca and others. Polychaetes and amphipods were constituted the highest number of species among the other groups. Seaweeds were more favourable for syllid polychaetes than seagrass. Melita zeylanica and Maera quadrimana were commonly distributed in both habitats at all stations. Paradexamine rewa was only recorded from seagrasses of Wett hay station. The associated faunas were more favourable to inhabit in seaweeds than seagrasses. The composition and distribution of associated faunas were varied with seaweeds and seagrasses according to their different structure of plants, types of substrate and sediment retention capacity.
\end{abstract}

Keywords: associated faunas, amphipods, polychaetes, seaweed, seagrass, Southern Rakhine coast
Volume 7 Issue 3 - 2018

\begin{abstract}
Aung Aung Htaik
Assistant Lecturer, Department of Marine Science, Mawlamyine University, Myanmar
\end{abstract}

\begin{abstract}
Correspondence: Aung Aung Htaik, Assistant Lecturer, Department of Marine Science, Mawlamyine University, Myanmar, Email uaungaunghtaik@gmail.com
\end{abstract}

Received: May 31, 2018| Published: June 22, 2018

\section{Introduction}

Marine environments, such as mangroves, coral reefs, seaweeds and seagrasses, are important for marine organisms. Seaweed and seagrass habitats support as the primary producer to link with higher trophic level in the marine food chain. Not only their physical structure (blades and leaves) provides food for invertebrate and vertebrate grazers but their highly organic content substrate persuades to detritus and deposit feeders. The diversity and abundance of benthic fauna may vary based on their habitat preference. Anandavelu ${ }^{1}$, Sarma \& Ganapati ${ }^{2}$, Sarma et al., ${ }^{3}$ Jansi \& Ramadhas ${ }^{4}$ found that the physical and developmental state of algae affected on the composition and abundance of phytal fauna. Moreover the capacity of sediment retaining of the algae was also influenced on the density of some organisms like foraminiferans, polychaetes and nematodes. Naufal \& Padmavati ${ }^{5}$ also stated that the plant morphology of different seagrass species influence on associated faunal communities.

Benthic faunal studies on different substrate (sand, mud and mangrove swamp) were made from the different coastal regions of the world. But those on the micro- and macrobenthic fauna associated with seaweeds and seagrasses were little. Ranjitham et al., ${ }^{6}$ studied the associated fauna of seaweeds and seagrasses in Vellar estuary. Jansi and Ramadhas ${ }^{4}$ recorded the diversity of fauna associated with four different species of seaweeds of Manakkudy estuary. Jaya et al., ${ }^{7}$ reported the diversity of meiofauna associated with nine different species of algae at Visakhapatnam coast. Azhagu et al., ${ }^{8}$ recorded twenty-one species of associated fauna in Chaetomorpha aerea. Muralikrishnamurty ${ }^{9}$ studied the distribution of phytal macro and meiofauna on nine species of intertidal algae off Gangavaram, East coast of India. In Myanmar, Ei Ei Mon ${ }^{10}$ studied the invertebrate fauna associated with red seaweed, Laurcencia sp. from Setse and Kyaikkhami coastal areas. The objective of this study is to know the species composition and distribution of associated fauna inhabited in the seaweeds and seagrasses from the Southern Rakhine coastal zone.

\section{Materials and Methods}

The study areas, Chaungtha (Lat. 16²57’N, Long. 94²6’E), Magyi
(Lat. $17^{\circ} 5^{\prime} \mathrm{N}$ and Long. $94^{\circ} 27^{\prime} \mathrm{E}$ ) and Wetthay (Lat. $17^{\circ} 10^{\prime} \mathrm{N}$ and Long. $94^{\circ} 28^{\prime} \mathrm{E}$ ), were situated in the Ayeyarwaddy Region, Southern part of Rakhine coast. Sampling location from the study areas are shown in Figure 1. Seaweeds and seagrass samples were collected randomly from each station at low tide. A PVC frame of $50 \mathrm{~cm} \times 50 \mathrm{~cm}$ was placed over the area covered by seaweeds and seagrasses and the contents of which are picked up and kept immediately in plastic bag separately and preserved in 5\% of formaldehyde and seawater. Plants are rinsed thoroughly with water and shaken to dislodge the fauna from them. The specimens were taken into a Petri dish and carefully examined under a binocular microscope. The faunas (polychaetes, mollusks, amphipods, isopods) are identified to genus or species level as possible and others are group (phylum) level in the laboratory by using compound microscope. The identifications are followed by Barnard ${ }^{11,12}$ Dance ${ }^{13}$ Day ${ }^{14}$ Fish and Fish ${ }^{15}$ Myers. ${ }^{16}$

\section{Results and Discussion}

The investigation of associated fauna from three stations of Southern Rakhine coastal zone showed that the presence of a high diversity polychaetes and amphipods. Moreover, a number of isopods, gastropods and ostracod were also recorded. In the present study, a total of 62 species of associated faunas were recorded in seaweeds and seagrasses from three stations (Table 1) (Figures 2-63). Of these, 34 species of polychaetes, 9 species of amphipods, 7 species of mollusks, 4 species of isopods, 2 species of tanaids and 1 species of Platyhelminthes, Nemartina, sipunculid and echinoderm respectively. The percentage of faunal composition was represented by $55 \%$ of Annelida, 27\% of Arthropoda, $11 \%$ of Mollusca and others. Jaya et al., ${ }^{7}$ recorded 18 diverse taxa of meiobenthos from the different species of algae at Visakhapatnam coast. The rich variety of nematodes, harpacticoids, amphipods, polychaetes, ostracods and gastropods were revealed from the four species of algae in Vellar estuary by Ranjitham et al., ${ }^{16}$ Azhagu Raj et al., ${ }^{8}$ Muralikrishnamurty ${ }^{9}$ found that associated faunal groups like isopods, gastropods, polychaetes and amphipods were high number in the intertidal algae off Gangavaram coast. Azhagu Raj ${ }^{8}$ recorded twenty one species of seaweed associated fauna from Pulicat estuary. 
Table I Classified list of associated faunas

\begin{tabular}{|c|c|c|c|c|c|c|}
\hline Phylum & Class & Order & Family & Genus & Sr.No. & Species \\
\hline Platyhelmi-nthes & Turbellaria & Polycladida & Leptoplani-dae & Leptoplana & $\mathrm{I}$. & Leptoplana sp. \\
\hline Sipunculid-ae & & & & & 2. & Sipunculid worm \\
\hline Nemertina & Anopla & & & & 3. & Nemertine sp. \\
\hline \multirow[t]{28}{*}{ Annelida } & Polychaeta & Phyllocida & Polynoidae & Paralepidonotus & 4. & Paralepidonotus sp. \\
\hline & & Flabelliger-ida & Flabelliger-idae & Piromis & 5. & Piromis sp. \\
\hline & & Capitellida & Maldanidae & Clymenura & 6. & Clymenura sp. \\
\hline & & & & Euclymene & 7. & Euclymene lunderitziana Augener \\
\hline & & & & & 8. & E. oerstedi Day \\
\hline & & & Capitellida & Praxillella & 9. & Praxillella sp. \\
\hline & & Opheliida & Opheliidae & Polyophthalmus & 10. & Polyophthalmus pictus Dujardin \\
\hline & & & & & II. & Polyophthalmus sp. \\
\hline & & Phyllodoci-da & Syllidae & Syllis & 12. & Syllis amica Quatrefages \\
\hline & & & & & 13. & S. hyalina Grube \\
\hline & & & & & 14. & S. exilis Gravier \\
\hline & & & & & 15. & S. gracilis Grube \\
\hline & & & & & 16. & S. nigropharyngea Day \\
\hline & & & & Trypanosyllis & 17. & Trypanosyllis sp. \\
\hline & & & & Pionosyllis & 18. & Pionosyllis malmgreni Mclnlosh \\
\hline & & & & Spermosyllis & 19. & Spermosyllis capensis Day \\
\hline & & & & Sphaerosyllis & 20. & Sphaerosyllis semiverrucosa Ehlers \\
\hline & & & & Autolytous & 21. & Autolytous sp. \\
\hline & & & Orbinidae & Scoloplos & 22. & Scoloplos sp. \\
\hline & & & Scalibreg-midae & Hyboscolex & 23. & Hyboscolex sp. \\
\hline & & & Eunicidae & Lysidice & 24. & $\begin{array}{l}\text { Lysidice ninetta Audouin \& Milne } \\
\text { Edwards }\end{array}$ \\
\hline & & & & Nematonereis & 25. & Nematonereis unicornis Grube \\
\hline & & & & Arabella & 26. & Arabella iricolor Montagu \\
\hline & & Phyllodoci-da & Nereididae & Platynereis & 27. & Platynereis isolita Gravier \\
\hline & & & & Nereis & 28. & Nereis jacksoni Kinberg \\
\hline & & & & & 29. & N. trifasciata Grube \\
\hline & & & & & 30. & N. persica Fauvel \\
\hline & & & & & 31. & N. operta Stimpson \\
\hline
\end{tabular}




\begin{tabular}{|c|c|c|c|c|c|c|}
\hline Phylum & Class & Order & Family & Genus & Sr.No. & Species \\
\hline \multirow[t]{6}{*}{ Annelida } & Polychaeta & Phyllodoci-da & Nereididae & Ceratonereis & 32. & Ceratonereis mirabilis Kinberg \\
\hline & & & & Perinereis & 33. & Perinereis capensis Kinberg \\
\hline & & Sabellida & Sabellidae & Euchone & 34. & Euchone sp. \\
\hline & & & & Oriopsis & 35. & Oriopsis sp. \\
\hline & & Terebellida & Terebellid-ae & Terebella & 36. & Terebella ehrenbergi Grube \\
\hline & & & Serpulidae & Hydroides & 37. & Hydroides uncinata Philippi \\
\hline \multirow[t]{7}{*}{ Mollusca } & Polyplaco-phora & Chitonida & Chaetople-uridae & Chaetopleura & 38. & Chaetopleura sp. \\
\hline & Gastropoda & Neogastro-poda & Columbell-idae & Pyrene & 39. & Pyrene sp. \\
\hline & & & Mitridae & Mitra & 40. & Mitra sp. \\
\hline & & Mesogastr-opoda & Cerithidae & Cerithium & 41. & Cerithium sp. \\
\hline & Bivalvia & Pelecypoda & Cardiidae & Clinoardium & 42. & Clinoardium sp. \\
\hline & & & Mytilidae & Mactra & 43. & Mactra sp. \\
\hline & & & & Setifera & 44. & Setifera sp. \\
\hline \multirow[t]{17}{*}{ Arthropoda } & Crustacea & Ostracoda & & & 45. & Ostracod \\
\hline & & Pantogoda & Pycnogon-idae & Pycnogonum & 46. & Pycnogonum sp. \\
\hline & & Amphipoda & Dexamini-dae & Paradexamine & 47. & Paradexamine rewa Myers \\
\hline & & & Eophlianti-dae & Bircenna & 48. & Bircenna dronga Myers \\
\hline & & & Hyalidae & Hyale & 49. & Hyale galateae distorta Myers \\
\hline & & & & Parhyale & 50. & Parhyale hawaiensis Dana \\
\hline & & & Isaeidae & Gammaropsis & 51. & $\begin{array}{l}\text { Gammaropsis atlantica } \\
\text { Stebbing }\end{array}$ \\
\hline & & & Gammari-dae & Melita & 52. & Melita zeylanica Stebbing \\
\hline & & & & Elasmopus & 53. & Elasmopus rapax Costa \\
\hline & & & & & 54. & E. pectenicrus Bate \\
\hline & & & & Maera & 55. & Maera quadrimana Dana \\
\hline & & Tanaidacea & Apseudid-ae & Apseudes & 56. & Apseudes sp. \\
\hline & & & Paratanaid-ae & Paratanais & 57. & Paratanais batei Sars \\
\hline & & Isopoda & Gnathiidae & Gnathia & 58. & Gnathia maxillaries M. Edw \\
\hline & & & & & 59. & Gnathia sp. \\
\hline & & & Aegidae & Aega & 60. & Aega tridens Leach \\
\hline & & & & & 61. & Aega sp. Lutken \\
\hline $\begin{array}{l}\text { Echinoder- } \\
\text { mata }\end{array}$ & Ophiuroid-ea & & & & 62. & Ophiuroid brittle star \\
\hline
\end{tabular}




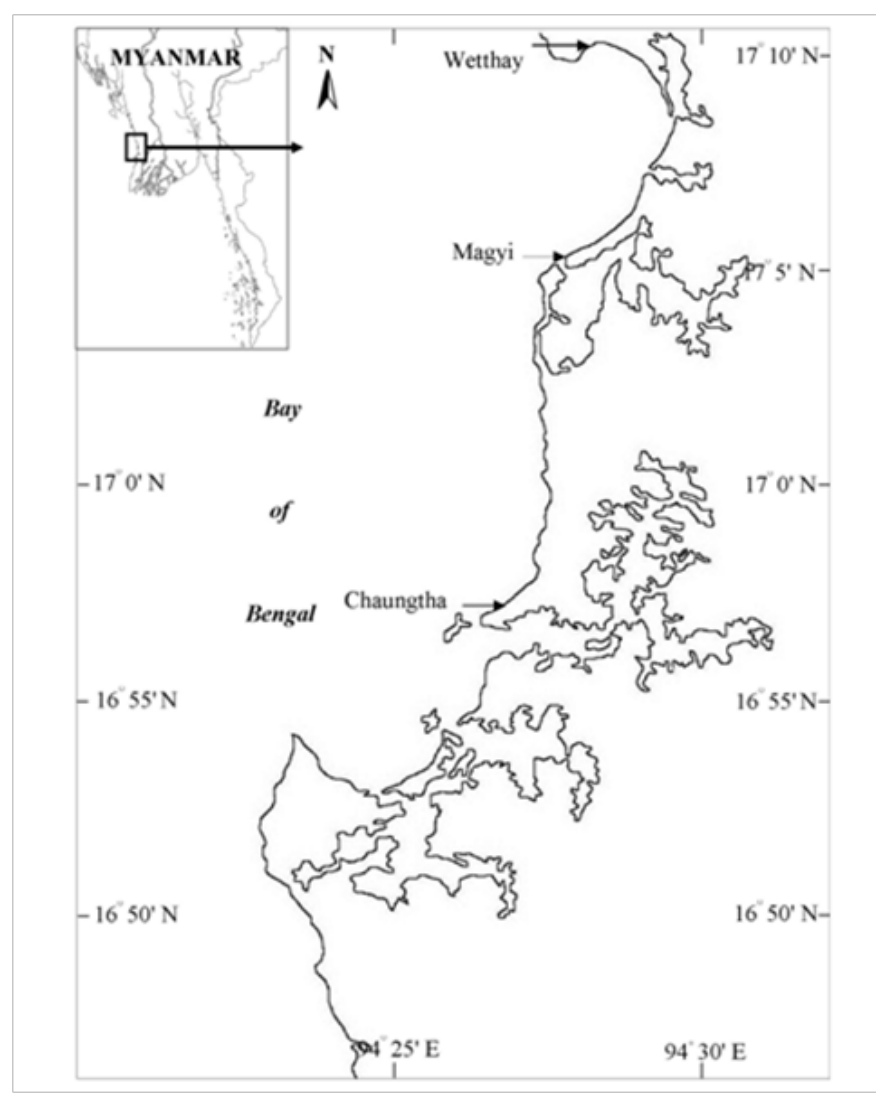

Figure I Map showing the sample collection sites of the study area.

The distribution and composition of associated fauna from three stations was presented in Figures 64-66 and (Table 2). It can be seen clearly that seaweeds were more favourable for associated faunas to inhabit than seagrasses. Sarma ${ }^{17}$ suggested that the stable sediment of algal belts, the fronds of algae and the organic detritus content in sediment from the death and decay of algal fronds were supported to different types of organisms. Moreover, the polychaetes were also the highest diversity of species among the other groups in all stations. In contrast to seagrass habitats, seaweed habitats were more number of polychaete species. It may be due to the different structure of plants, types of substratum and the ability of sediment retained by plant Sarma ${ }^{17}$, Sarma et al., ${ }^{3}$ Ranjitham et al., ${ }^{6}$ Azhagu Raj et al., ${ }^{8}$ Muralikrishnamurty, ${ }^{9}$ Sarma and Gnapati ${ }^{2}$, Pati et al., ${ }^{18}$ and Mohan Joseph $^{19}$. Naufal ${ }^{5}$ found that the morphology of the different leaf blades of the seagrass species was a major factor for the attachment of organisms. Ranjitham et al., ${ }^{6}$ reported that the environmental factors including temperature, salinity, turbidity, oxygen concentration, pollution, water movement and level of nutrients also influence animal distributions. Anandavelu et al., ${ }^{1}$ suggested that the sediment retention capacity of weeds might play an important role on the assemblage of epifaunal community. Ranjitham et al., ${ }^{6}$ Jansi and Ramadhas ${ }^{9}$ found that the filamentous algae of Enteromorpha compressa with poor sediment retention capacity may be comparatively lower faunal association than that of other algae.

In this present study, maldanid and syllid polychaetes were constituted in great quantities. The maldanids are highly specialized burrowers feeding on organic particles buried in the mud Day. ${ }^{14}$ They can be found in the tube forms attached to seaweeds. Mohan Joseph ${ }^{19}$ stated that the majority of polychaetes inhabited in algal fronds were the tube dwelling or living in the sediments retained by the holdfast.

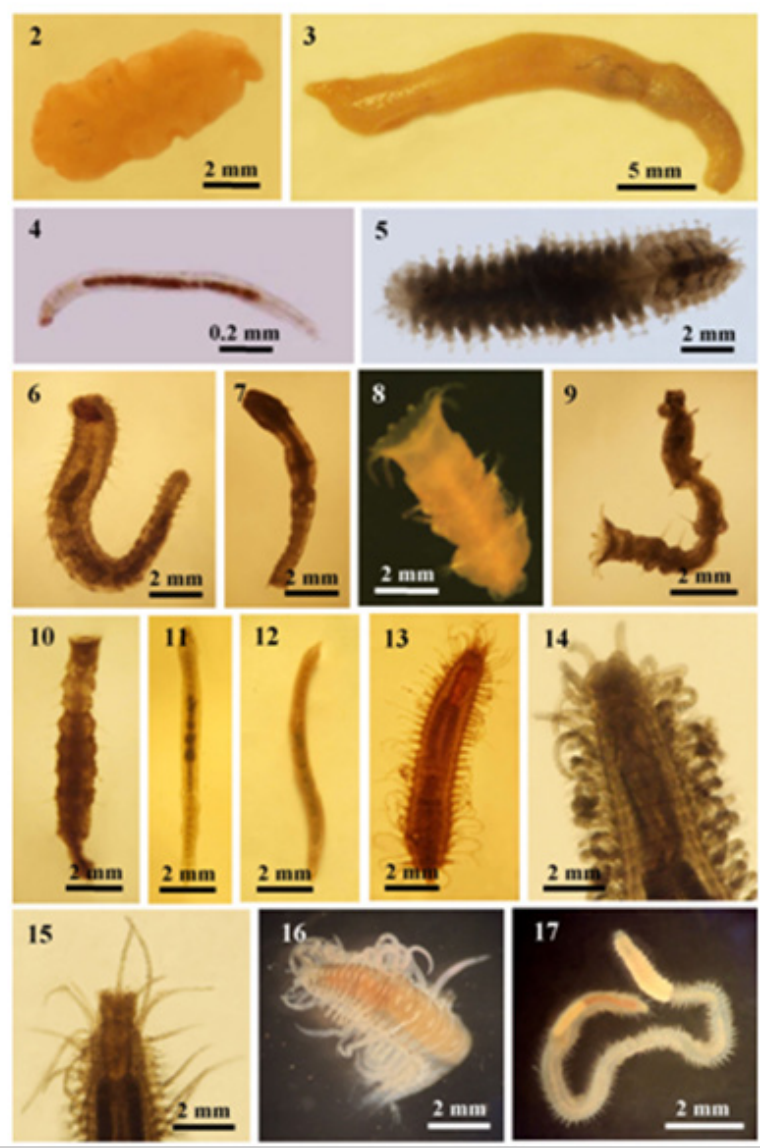

Figures 2-I7 Associated faunas. (2) Leptoplana sp., (3) Sipunculid worm. (4) Nemertine sp., (5) Paralepidonotus sp., (6) Piromis sp., (7) Clymenura sp., (8) Euclymene lunderitziana, (9) E. oerstedi, (I0) Praxillella sp., (II) Polyophthalmus pictus. (I2) Polyophthalmus sp., (13) Syllis amica (14) S. hyaline (15) S. gracilis (16) S. exilis (17) S. nigropharyngea.

The syllids are also a large and diverse group of small active worms in this present study and most of which are found creeping over algae. Ei Ei Mon ${ }^{10}$ indicated that the syllid polychaetes were outnumbered in Laurcencia sp. of Kyaikkhami coastal area. Mohan Joseph ${ }^{19}$ found that Syllis (Typosyllis) krohnii and Syllis prolifera were abundant in the sediments retained by the algae. Nereid polychaetes are also equally diverse group and inhabited among the complex structures of seaweeds and seagrasses.

A large variety of amphipods and isopods were also found in this study. Their grasping appendages could hold firmly the cylindrical filaments of the algae Sarma and Gnapti. ${ }^{2}$ Melita zeylanica and Maera quadrimana were commonly distributed in both habitats at all stations. Paradexamine rewa was only recorded from seagrasses of Wetthay station. Ranjitham et al., ${ }^{6}$ suggested that seagrass fauna rarely associate to particular seagrass species but respond to a restricted set of physical environmental parameters. Consequently many animal species are common to adjacent beds of different seagrass speices. The bivalve mytilid mollusks were endowed with their by ssus adhere to the holdfasts of the seaweeds. The gastropods, Pyrene sp. and Mitra sp. were distributed on both habitats. Leptoplana sp., the ophiuroids, Pycnogonum sp. and nemartine were also distributed in both seaweeds and seagrasses. 
Table 2 The distribution of associated faunas along the study areas

\begin{tabular}{|c|c|c|c|c|c|c|c|}
\hline \multirow{2}{*}{ No. } & \multirow{2}{*}{ Species name } & \multicolumn{2}{|c|}{ Chaungtha } & \multicolumn{2}{|l|}{ Magyi } & \multicolumn{2}{|l|}{ Wetthay } \\
\hline & & seaweed & seagrass & seaweed & seagrass & seaweed & seagrass \\
\hline $\mathrm{I}$. & Leptoplana sp. & + & + & + & + & + & + \\
\hline 2 & Sipunculid worm & + & + & - & - & - & - \\
\hline 3. & Nemertine sp. & + & + & + & + & + & + \\
\hline 4. & Paralepidonotus sp. & + & + & - & - & + & - \\
\hline 5. & Piromis sp. & + & - & - & - & - & - \\
\hline 6. & Clymenura sp. & + & - & - & - & + & - \\
\hline 7. & Euclymene lunderitziana & + & - & + & - & - & - \\
\hline 8. & E. oerstedi & + & - & - & - & - & - \\
\hline 9. & Praxillella sp. & + & - & - & - & + & - \\
\hline 10. & Polyophthalmus pictus & + & - & + & - & + & - \\
\hline II. & Polyophthalmus sp. & + & - & + & - & + & - \\
\hline 12. & Syllis amica & + & - & + & - & - & - \\
\hline 13. & S. hyalina & + & - & - & - & - & - \\
\hline 14. & S. exilis & - & - & + & - & + & - \\
\hline 15. & S. gracilis & - & - & + & - & - & - \\
\hline 16. & S. nigropharyngea & + & - & - & - & - & - \\
\hline 17. & Trypanosyllis sp & - & - & - & - & - & - \\
\hline 18. & Pionosyllis malmgreni & + & - & - & - & - & - \\
\hline 19. & Spermosyllis capensis & + & - & - & - & - & - \\
\hline 20. & Sphaerosyllis semiverrucosa & - & - & + & - & - & - \\
\hline 21. & Autolytous sp. & - & - & - & - & + & - \\
\hline 22. & Scoloplos sp & - & + & - & - & - & - \\
\hline 23. & Hyboscolex sp. & - & - & - & - & + & - \\
\hline 24. & Lysidice ninetta & - & + & - & + & - & - \\
\hline 25. & Nematonereis unicornis & + & + & - & - & - & - \\
\hline 26. & Arabella iricolor & - & - & - & - & + & - \\
\hline 27. & Platynereis isolita & - & - & - & - & + & + \\
\hline 28. & Nereis jacksoni & + & + & - & - & - & - \\
\hline 29. & N. trifasciata & - & - & + & + & + & + \\
\hline 30. & N. persica & - & - & + & + & + & + \\
\hline 31. & N. operta & - & - & + & + & + & + \\
\hline 32. & Ceratonereis mirabilis & + & + & + & + & + & + \\
\hline 33. & Perinereis capensis & + & - & - & - & - & - \\
\hline 34. & Euchone sp. & - & - & + & - & + & - \\
\hline 35. & Oriopsis sp. & + & - & + & - & + & - \\
\hline 36. & Terebella ehrenbergi & + & + & - & - & + & + \\
\hline 37. & Hydroides uncinata & - & - & + & - & - & - \\
\hline 38. & Chaetopleura apiculata & + & - & + & - & - & - \\
\hline 39. & Pyrene sp. & + & + & - & - & - & \\
\hline 40. & Mitra sp. & + & + & + & + & + & + \\
\hline $4 \mathrm{I}$. & Cerithium sp. & - & - & + & + & + & + \\
\hline 42. & Clinocardium sp. & - & - & - & - & + & + \\
\hline 43. & Mactra sp. & + & + & + & + & - & \\
\hline 44. & Setifera sp. & + & + & + & + & + & + \\
\hline 45. & Ostracod sp. & + & - & - & - & + & + \\
\hline 46. & Pycnogonum sp. & + & + & + & + & + & + \\
\hline 47. & Paradexamine rewa & - & - & - & - & - & + \\
\hline
\end{tabular}




\begin{tabular}{|c|c|c|c|c|c|c|c|}
\hline \multirow{2}{*}{ No. } & \multirow{2}{*}{ Species name } & \multicolumn{2}{|c|}{ Chaungtha } & \multicolumn{2}{|l|}{ Magyi } & \multicolumn{2}{|l|}{ Wetthay } \\
\hline & & seaweed & seagrass & seaweed & seagrass & seaweed & seagrass \\
\hline 48. & Bircenna dronga & - & - & - & - & + & + \\
\hline 49. & Hyale galateae distorta & + & - & + & - & - & - \\
\hline 50. & Parhyale hawaiensis & + & . & + & + & + & + \\
\hline 51. & Gammaropsis atlantica & - & - & + & + & + & + \\
\hline 52. & Melita zeylanica & + & + & + & + & + & + \\
\hline 53. & Elasmopus rapax & + & - & - & - & + & + \\
\hline 54. & E. pectenicrus & & + & - & - & - & - \\
\hline 55. & Maera quadrimana & + & + & + & + & + & + \\
\hline 56. & Apseudes sp. & - & - & + & - & - & - \\
\hline 57. & Paratanais batei & - & + & - & - & - & - \\
\hline 58. & Gnathia maxillaries & - & - & + & + & + & + \\
\hline 59. & Gnathia sp. & - & - & - & + & - & + \\
\hline 60. & Aega tridens & + & - & - & + & - & - \\
\hline 61. & Aega sp. & - & - & - & - & - & + \\
\hline \multirow[t]{2}{*}{62.} & Ophiuroid brittle star & + & + & + & + & + & + \\
\hline & Total & 36 & 20 & 30 & 20 & 33 & 25 \\
\hline
\end{tabular}

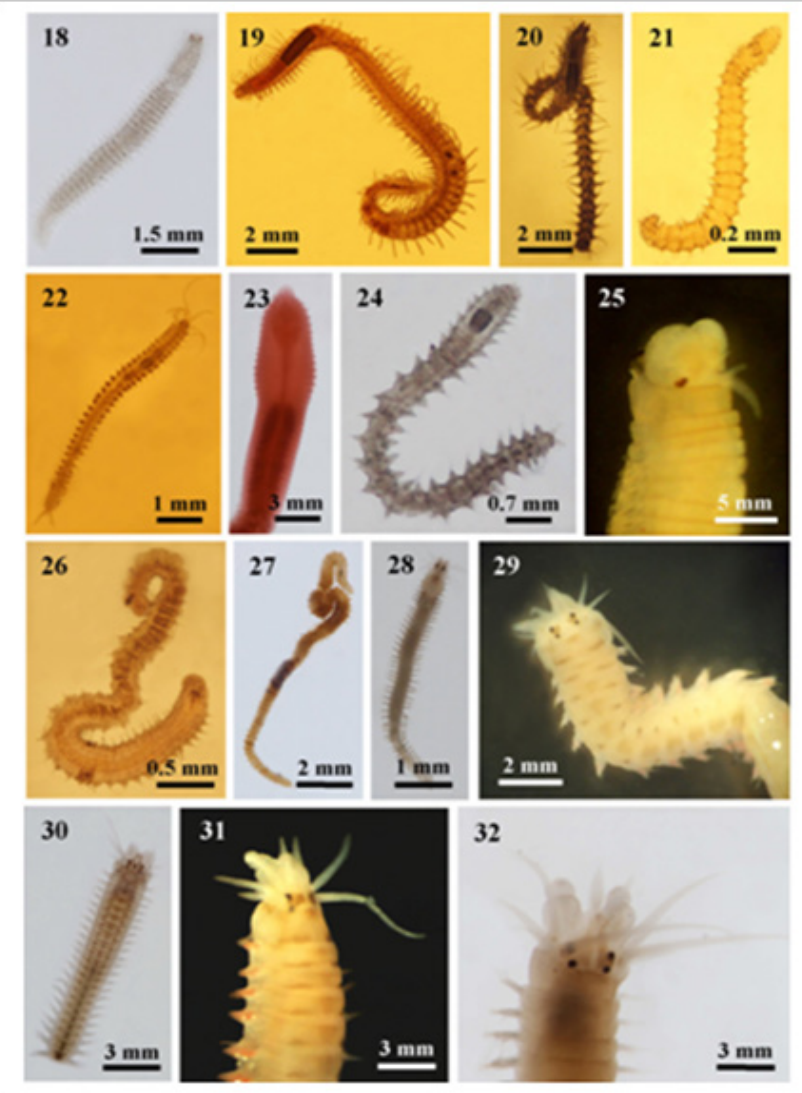

Figures 18-32 Associated faunas. (18) Trypanosyllis sp., (19) Pionosyllis malmgreni, (20) Spermosyllis capensis, (2I) Sphaerosyllis semiverrucosa, (22) Autolytous sp., (23) Scoloplos sp., (24) Hyboscolex sp., (24) Lysidice ninetta, (25) Nematonereis unicornis (26) Arabella iricolor (27) Platynereis isolita (28) Nereis jacksoni (29) N. trifasciata, (30) N. persica (3I) N. operta.
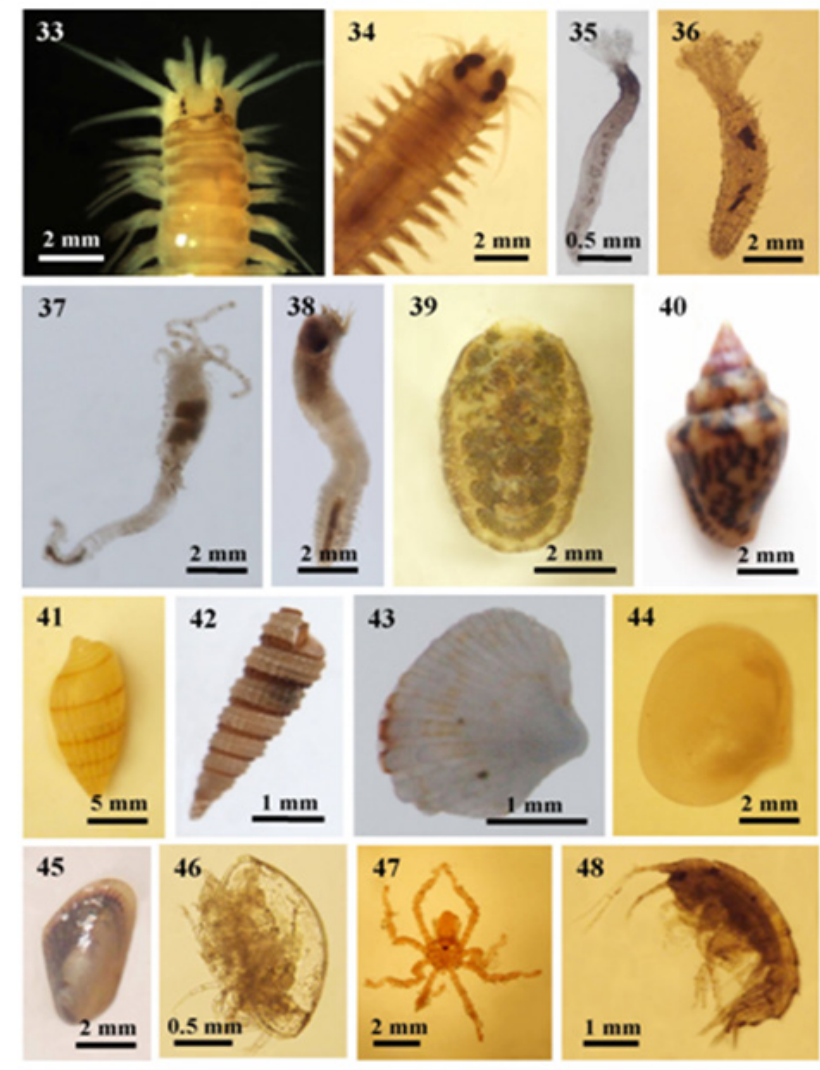

40

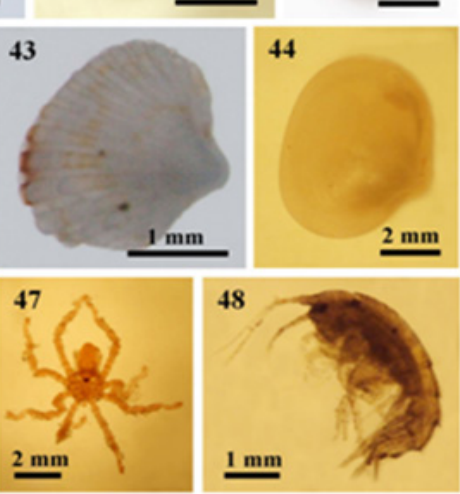

Figures 33-48 Associated faunas. (33) Ceratonereis mirabilis (34) Perinereis capensis (35) Perinereis capensis, (36) Oriopsis sp., (37) Terebella ehrenbergi (38) Hydroides uncinata (39) Chaetopleura sp., (40) Pyrene sp., (4I) Mitra sp. (42) Cerithium sp. (43) Clinoardium sp., (44) Mactra sp., (45) Setifera sp., (46) Ostracod (47) Pycnogonum sp., (48) Paradexamine rewa. 


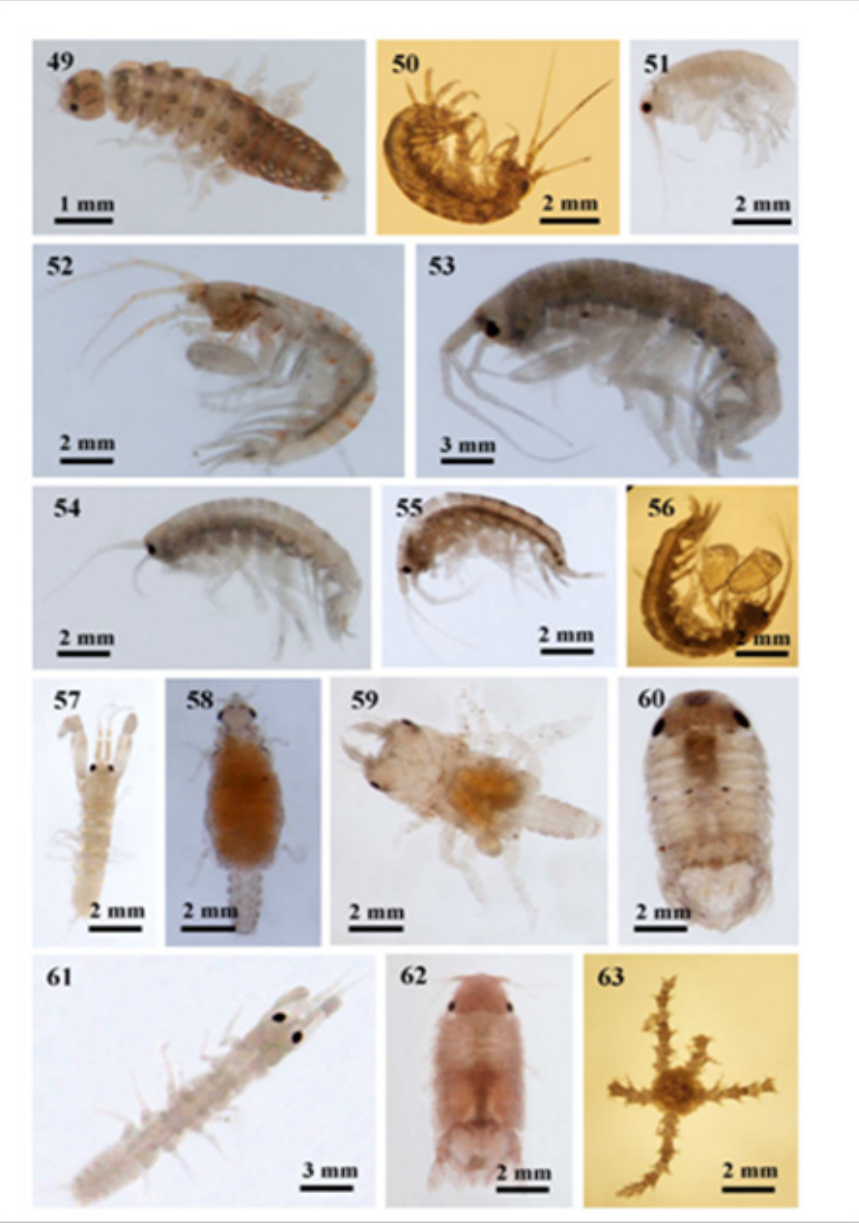

Figures 49-63 Associated faunas. (49) Bircenna dronga (50) Hyale galateae distorta (5I) Parhyale hawaiensis (52) Gammaropsis atlantica (53) Elasmopus pectenicrus (54) E. rapax (55) Melita zeylanica (56) Maera quadrimana (57) Apseudes sp., (58) Gnathia maxillaries (59) Gnathia sp., (60) Aega tridens (6I) Paratanais batei (62) Aega sp., (63) Ophiuroid brittle star.

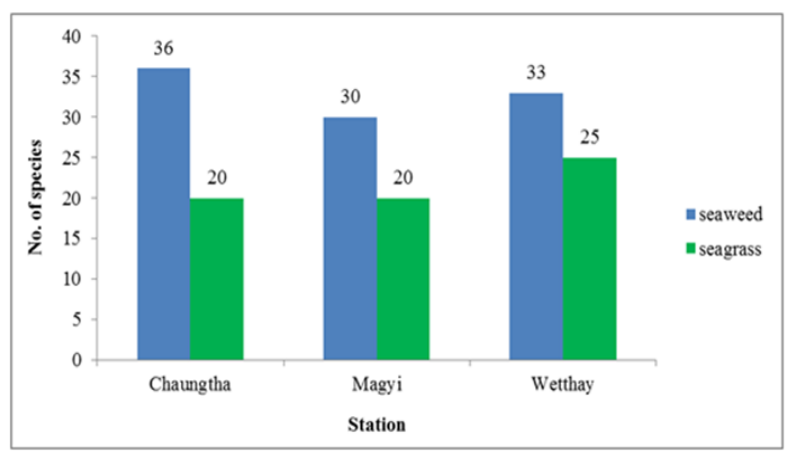

Figure 64 The composition of associated faunas in seaweeds and seagrasses from three stations.

Many species inhabiting seaweeds and seagrasses depend on them for food. The most common are polychaetes, amphipods and gastropods. The feeding relationship of the faunas was also varied. Many are filter feeders, detritus feeders, scavengers or carnivores; algivores ranging from minute crustaceans to large sized gastropods Sarma \& Gnapati, Ranjitham, Azhagu Raj, Mohan Joseph, Sarma, et al. $2,6,8,17,19$
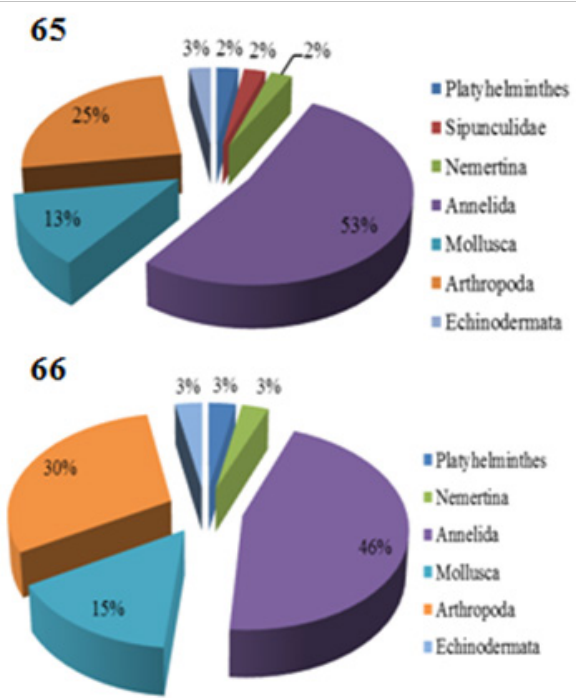

67

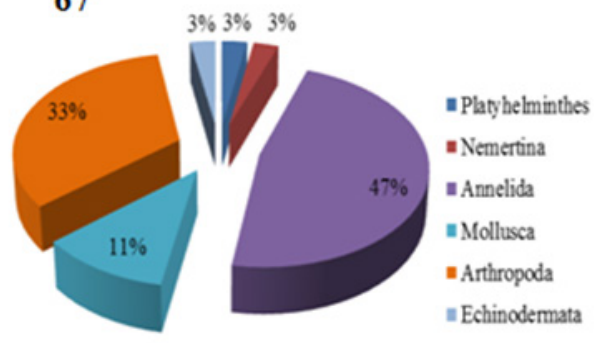

Figures 65-67 Percentage composition of associated faunas in seaweeds and seagrasses from three.

\section{Conclusion}

It is well known from this study that seaweed and seagrass habitats provide high diversity of associated fauna. These habitats are important for shallow water marine organisms in order to get food and shelter from biotic and abiotic factors (predators and waves). This study revealed that baseline information for associated faunas of seaweeds and seagrasses from Southern Rakhine Costal zone. Seasonal and spatial abundance of associated fauna with respect to these habitats should be continued thoroughly in future. Because of seaweeds and seagrasses and their associated fauna support directly and indirectly to the route of energy transfer linked with the higher trophic level in marine food web, they are needed to be protected from human activities like overharvesting of seaweeds and seagrass from their habitats, habitats lost by coastal development, recreational activities and beach cleaning.

\section{Acknowledgements}

I am indebted to Dr. Aung Myat Kyaw Sein, Acting-Rector, and Dr. Mie Mie Sein and Dr. San San Aye, Pro-Rectors, Mawlamyine University, for their supports and encouragement in this study. I am grateful to Dr. San Tha Tun, Professor, Head of Department of Marine Science, Mawlamyine University, for providing equipment in this research. I would like to thank U Soe-Htun, Professor (Retd.), Head of Department of Marine Science, Mawlamyine University and Chairman of Marine Science Association, Myanmar (MSAM) for his generous supports and useful suggestions, in the preparation of the manuscript. 


\section{Conflict of interest}

The author declares that there is no conflict of interest.

\section{References}

1. Anandavelu I, Jayabarathi R, Padmavati G, et al. Epifaunal assemblage on morphologically distinct intertidal seaweeds of Kodiyaghat (South Andaman), India. Proceedings of the International Academy of Ecology and Environmental Sciences. 2013;3(3):229-237.

2. Sarma ALN, Ganapati PN. Faunal associations of algae in the intertidal region of Visakhapatnam. Proc. Indian natn Sci Acad. 1972;(B)38:380396.

3. Sarma ALN, Satapathy S, Rao DG. Phytal macro \& meiofauna of Chilka Lake. Indian Journal of Marine Sciences.1981;10:61-65.

4. Jansi M, Ramadhas V. Diversity of fauna associated with four different species of seaweeds of Manakkudy estuary. Seshaiyana. 2009;17(1):1-3.

5. Naufal PJ, Padmavati G. 2018. Meiofaunal distribution and abundance from the intertidal seagrass patches of Chidiyatapu, Port Blair. Indian Journal of Geo Marine Sciences. 2018;47(02):357-364.

6. Ranjitham NS, Thirumaran G, Anantharaman P, et al. Associated fauna of seaweeds and seagrasses in Vellar estuary. American-Eurasian Journal of Botany. 2008;1(1):9-16.

7. Jaya P, Annapurna C, Bhanu V. Diversity of meiofauna associated with nine different species of algae at Visakhapatnam coast. IJBPAS. 2012;1(4):469-483.

8. Azhagu Raj R, Ganesh J, Prakasam A, et al. Fauna associated with the marine macro alga Chaetomorpha aerea (Dillwyn) Kutzing, (Chlorophyceae) in Pulicat estuary, Tamil Nadu, India. International Journal of Fisheries and Aquatic Studies. 2017;5(1):319-326.
9. Muralikrishnamurty PV. Intertidal phytal fauna off Gangavaram, East coast of India. Indian Journal of Marine Sciences. 1983;12:85-89.

10. Ei Ei Mon. Study on the invertebrate fauna associated with red seaweed, Laurcencia sp. from Setse and Kyaikkhami, Mon State. Unpublished M.Sc. Thesis. Department of Marine Science, Mawlamyine University, Mawlamyine, Myanmar. 2010.

11. Barnard JL. Gammaridean Amphipoda of Australia. Part I. 1972; 334 p.

12. Barnard JL. Gammaridean Amphipoda of Australia. Part II. 1974; 160 p.

13. Dance SP. Shells. Smithsonian Handbooks. 2002; pp. 1-256.

14. Day JH. A monograph on the polychaeta of Southern Africa. The British Natural History Museum. London. 1967; 878 p.

15. Fish JD, Fish S. A student's guide to the sea shore. Cambridge University Press. 2011; 1-573.

16. Myers AA 1985. Shallow-water, coral reef and mangrove Amphipoda (Gammaridea) of Fiji. Records of the Australian Museum, Supplement. 1985;5:1-143.

17. Sarma ALN. Phytal fauna of Caulerpa taxifolia \& C. racemosa off Visakhapatnam coast. Indian Journal of Marine Sciences, 1974;3(2):155164.

18. Pati MP, Nayak L, Sharma SD. Studies on biomass of seagrass, seaweed and its associated fauna from Chilika lagoon. International Journal of Environmental Sciences. 2014;5(2):423-431.

19. Mohan Joseph M. Ecological studies on the fauna associated with economic seaweeds of south India. I. Species composition, feeding habits and interrelationship. Seaweed Res. Util. 1978:3:8-25. 